\title{
Effects and Mechanisms of Calcium Ion Addition on Lead Removal from Water by Eichhornia crassipes
}

\author{
Jin-mei Zhou ${ }^{1,2,3, *}$, Zhong-cheng Jiang ${ }^{1,3,4, *}$, Xiao-qun Qin ${ }^{1,3}$, Lian-kai Zhang ${ }^{1,3}$, \\ Qi-bo Huang ${ }^{1}$ and Guang-li Xu ${ }^{2}$ \\ 1 Institute of Karst Geology, Chinese Academy of Geological Sciences, Guilin 541004, China; \\ qxq@karst.ac.cn (X.Q.); zhangliankai@karst.ac.cn (L.Z.); qbohuang0108@163.com (Q.H.) \\ 2 Faculty of Engineering, China University of Geosciences, Wuhan 430074, China; xu1963@cug.edu.cn \\ 3 Key Laboratory of Karst Ecosystem and Treatment of Rocky Desertification, Ministry of Natural Resources, \\ Guilin 541004, China \\ 4 Key Laboratory of Karst Dynamics, Ministry of Natural Resources, Guilin 541004, China \\ * Correspondence: jinmzhou@163.com (J.Z.); zhjiang@karst.ac.cn (Z.J.)
}

Received: 12 December 2019; Accepted: 29 January 2020; Published: 2 February 2020

check for updates

\begin{abstract}
Karst water is rich in calcium ions $\left(\mathrm{Ca}^{2+}\right)$ and exhibits poor metal availability and low biodegradation efficiency. This study sought to analyze the effects and mechanisms of $\mathrm{Ca}^{2+}$ on lead $(\mathrm{Pb})$ removal and absorption by Eichhornia crassipes (a floating plant common in karst areas). Moreover, the morphology and functional groups of E. crassipes in water were characterized via $\mathrm{SEM}$, and FTIR. The results demonstrated that the removal rate of $\mathrm{Pb}$ in karst water $(85.31 \%)$ was higher than that in non-karst water (77.04\%); however, the Pb bioconcentration amount (BCA) in $E$. crassipes roots in karst water $(1763 \mathrm{mg} / \mathrm{kg})$ was lower than that in non-karst water $(2143 \mathrm{mg} / \mathrm{kg})$. With increased $\mathrm{Ca}^{2+}$ concentrations $(60,80$, and $100 \mathrm{mg} / \mathrm{L})$ in karst water, the Pb removal rate increased (85.31\%, 88.87\%, and 92.44\%), the Pb BCA decreased (1763, 1317, and $1095 \mathrm{mg} / \mathrm{kg}$ ), and the Ca BCA increased $\left(6801,6955\right.$, and $9368 \mathrm{mg} / \mathrm{kg}$ ), which was attributed to $\mathrm{PbCO}_{3}$ and $\mathrm{PbSO}_{4}$ precipitation and competitive $\mathrm{Ca}$ and $\mathrm{Pb}$ absorption. High $\mathrm{Ca}^{2+}$ concentrations increased the strength of cation exchange, alleviated the fracture degree of fibrous roots, reduced the atrophy of vascular bundles, protected the cell wall, promoted $\mathrm{C}-\mathrm{O}$ combined with $\mathrm{Pb}$, enhanced the strength of $\mathrm{O}-\mathrm{H}, \mathrm{SO}_{4}{ }^{2-}, \mathrm{C}=\mathrm{O}$, and reduced the oxidization of alkynyl acetylene bonds.
\end{abstract}

Keywords: Eichhornia crassipes; lead; calcium ion (II); alleviation; cation exchange; functional groups

\section{Introduction}

Karst water quality has begun to deteriorate in recent years due to increased industrial mining, agriculture, and other human activities. The "three wastes" generated by industrial and mining enterprises, municipal sewage discharge, and the use of heavy-metal-containing products have caused serious heavy metal environmental pollution [1]. Karst areas in China are mainly distributed in the southwestern region and are characterized by complex landforms and carbonate formations. Karst areas possess abundant groundwater resources, which are alkaline and rich in calcium ions $\left(\mathrm{Ca}^{2+}\right)$ and exhibit poor metal availability and low biodegradation efficiency. Notably, karst water is characteristically rich in $\mathrm{HCO}_{3}$-Ca due to the dissolution of carbonate rocks [2]. Moreover, due to its unique hydrologic double-layer structure (i.e., surface and underground water), karst water is easily polluted but difficult to treat once it has been contaminated by heavy metals [3]. Heavy metal pollution in karst water has become an urgent, worldwide problem. Lead $(\mathrm{Pb})$ is one of the most toxic heavy metal elements and has very long retention times, which is why it has become one of the most studied elements in the field of heavy metal pollution [4]. Aquatic $\mathrm{Pb}$ pollution mainly originates from 
industrial wastewater discharged by the lead smelting industry. $\mathrm{Pb}$ remains and accumulates in the food chain after entering the environment, which causes serious toxicity to organisms. Moreover, $\mathrm{Pb}$ affects plant photosynthesis and transpiration capacity [5,6]; therefore, $\mathrm{Pb}$ remediation has become the focus of many studies worldwide.

Eichhornia crassipes is an aquatic floating plant that is widely distributed all over the world and occurs in large quantities in karst areas in China. E. crassipes has broad, thick, glossy, ovate leaves and stems, which are important for photosynthesis, food production, gas exchange, and water transpiration [7]. This plant is known to adapt to a wide variety of environmental conditions and even grows well in sewage water. Importantly, E. crassipes possesses a high heavy metal tolerance and uptake efficiency and has therefore become popular for water phytoremediation [8]. E. crassipes can reproduce quickly and absorb various pollutants [9]. Suryandari et al. [10] also demonstrated $\mathrm{Pb}$ removal efficiencies of up to $99.71 \%$ in E. crassipes harvested after nine days.

Calcium (Ca) is an essential element for plants; it is an important regulator of plant growth and supports the structure and stability of cell walls, membranes, and membrane-binding proteins. Ca is also a second messenger that regulates the response of plants to environmental changes [11]. Moreover, certain $\mathrm{Ca}^{2+}$ concentrations could promote growth and development, metabolism, cell structure, and adaptability to heavy metal stress [12-14]. $\mathrm{Ca}^{2+}$ could also inhibit the transport of heavy metals from underground to aboveground plant structures [15]. Increased $\mathrm{Ca}^{2+}$ concentrations could reduce heavy metal solubility [16] and alleviate heavy metal phytotoxicity [17]. However, there is currently no consensus regarding the effects of $\mathrm{Ca}^{2+}$ on heavy metal accumulation in plants. Heeraman et al. [18] reported that high $\mathrm{Ca}^{2+}$ concentrations could promote the accumulation of arsenic in Zorro fescue (a grass species). In contrast, Calile et al. [16] demonstrated that $\mathrm{Ca}^{2+}$ had no apparent effect on the absorption of arsenic in the Chinese brake (Pteris vittata). Regardless of these discrepancies, high $\mathrm{Ca}^{2+}$ concentrations in karst water may be responsible for the higher heavy metal bioaccumulation capacity of some aquatic plants in karst waters than that in other environments [19]. However, the effects of $\mathrm{Ca}^{2+}$ on the $\mathrm{Pb}$ removal and accumulation capacity of E. crassipes in $\mathrm{Pb}$-contaminated karst water remain unclear.

Therefore, this study sought to characterize the effect of $\mathrm{Ca}^{2+}$ on the $\mathrm{Pb}$ removal efficiency of E. crassipes in karst water. This study employed Inductively Coupled Plasma Mass Spectrometry (ICP-MS), Scanning Electron Microscopy (SEM), Fourier-Transform Infrared Spectrometry (FTIR), and other methods to investigate the $\mathrm{Pb}$ removal efficiency and absorption capacity of E. crassipes in karst and non-karst water at different $\mathrm{Ca}^{2+}$ concentrations. This study thus provides a comprehensive analysis of the mechanisms by which $\mathrm{Ca}^{2+}$ modulates $\mathrm{Pb}$ uptake by E. crassipes in karst water under $\mathrm{Pb}$-induced stress, and provides a theoretical basis for the effective application of E. crassipes for $\mathrm{Pb}$ remediation in polluted karst water.

\section{Materials and Methods}

\subsection{Materials}

Similarly sized wild E. crassipes plants were collected from the Huixian wetland (Guilin, Guangxi, China), where these plants are abundant and widely distributed. After discarding decomposed leaves, the surface dirt on the remaining leaves was removed by repeatedly washing them with tap water and then with de-ionized water. The E. crassipes plants used herein had the following characteristics: weight, $150 \mathrm{~g}$; height, $30 \mathrm{~cm}$; Ca, 13,275 mg/kg; Mg, $2325 \mathrm{mg} / \mathrm{kg}$; K, 28,950 mg/kg; Na, 1198 mg/kg; P, 2695 mg/kg; Fe, 2570 mg/kg; Mn, 598 mg/kg; Pb, 2.46 mg/kg; Cd, 0.118 mg/kg; Cu, 16.5 mg/kg; Zn, $53.6 \mathrm{mg} / \mathrm{kg}$.

The karst and non-karst water used in the experiments were obtained from the outlets of the Mamian Shizishan underground river at Huixian and the Lijiang River in Guilin, respectively, using polyethylene barrels. Table 1 summarizes the karst and non-karst water hydrochemical parameters 
determined by this study. All chemicals used for experimental purposes were of analytical grade and were dissolved in de-ionized water.

Table 1. Hydrochemical parameters of karst water and non-karst water used in the experiments.

\begin{tabular}{|c|c|c|c|c|c|}
\hline Parameters & Karst Water & Non-karst Water & Parameters & Karst Water & Non-karst Water \\
\hline $\mathrm{pH}$ & 7.25 & 7.50 & $\mathrm{~K}^{+} / \mathrm{mg} \cdot \mathrm{L}^{-1}$ & 3.46 & 1.95 \\
\hline $\mathrm{Pb} / \mu \mathrm{g} \cdot \mathrm{L}^{-1}$ & $<0.07$ & $<0.07$ & $\mathrm{Na}^{+} / \mathrm{mg} \cdot \mathrm{L}^{-1}$ & 1.02 & 1.16 \\
\hline $\mathrm{Al} / \mu \mathrm{g} \cdot \mathrm{L}^{-1}$ & 38.5 & 41.9 & $\mathrm{Ca}^{2+} / \mathrm{mg} \cdot \mathrm{L}^{-1}$ & 57.06 & 23.42 \\
\hline $\mathrm{Zn} / \mu \mathrm{g} \cdot \mathrm{L}^{-1}$ & 0.88 & 4.29 & $\mathrm{Mg}^{2+} / \mathrm{mg} \cdot \mathrm{L}^{-1}$ & 3.66 & 1.33 \\
\hline $\mathrm{Cr} / \mu \mathrm{g} \cdot \mathrm{L}^{-1}$ & 4.52 & 1.30 & $\mathrm{NH}_{4}^{+} / \mathrm{mg} \cdot \mathrm{L}^{-1}$ & 0.060 & $<0.02$ \\
\hline $\mathrm{Ni} / \mu \mathrm{g} \cdot \mathrm{L}^{-1}$ & 1.40 & 0.91 & $\mathrm{Cl}^{-} / \mathrm{mg} \cdot \mathrm{L}^{-1}$ & 3.04 & 5.25 \\
\hline $\mathrm{Co} / \mu \mathrm{g} \cdot \mathrm{L}^{-1}$ & $<0.03$ & $<0.03$ & $\mathrm{SO}_{4}{ }^{2-} / \mathrm{mg} \cdot \mathrm{L}^{-1}$ & 9.32 & 9.00 \\
\hline $\mathrm{Cd} / \mu \mathrm{g} \cdot \mathrm{L}^{-1}$ & $<0.06$ & $<0.06$ & $\mathrm{HCO}_{3}{ }^{-} / \mathrm{mg} \cdot \mathrm{L}^{-1}$ & 173.56 & 58.61 \\
\hline $\mathrm{Mn} / \mu \mathrm{g} \cdot \mathrm{L}^{-1}$ & 44.6 & 6.92 & $\mathrm{CO}_{3}{ }^{2-} / \mathrm{mg} \cdot \mathrm{L}^{-1}$ & 0.00 & 0.00 \\
\hline $\mathrm{As} / \mu \mathrm{g} \cdot \mathrm{L}^{-1}$ & 1.16 & 0.64 & $\mathrm{NO}_{3}{ }^{-} / \mathrm{mg} \cdot \mathrm{L}^{-1}$ & 0.84 & 8.17 \\
\hline $\mathrm{Hg} / \mu \mathrm{g} \cdot \mathrm{L}^{-1}$ & 37.8 & 1.15 & $\mathrm{NO}_{2}^{-} / \mathrm{mg} \cdot \mathrm{L}^{-1}$ & $<0.002$ & 0.002 \\
\hline $\mathrm{Cu} / \mu \mathrm{g} \cdot \mathrm{L}^{-1}$ & 0.48 & 0.98 & $\mathrm{~F}^{-} / \mathrm{mg} \cdot \mathrm{L}^{-1}$ & 0.078 & 0.080 \\
\hline $\mathrm{CO}_{2} / \mathrm{mg} \cdot \mathrm{L}^{-1}$ & 8.95 & 3.83 & $\mathrm{PO}_{4}{ }^{3-} / \mathrm{mg} \cdot \mathrm{L}^{-1}$ & 0.23 & 0.040 \\
\hline $\mathrm{SiO}_{2} / \mathrm{mg} \cdot \mathrm{L}^{-1}$ & 5.35 & 5.25 & $\mathrm{OH}^{-} / \mathrm{mg} \cdot \mathrm{L}^{-1}$ & 0.00 & 0.00 \\
\hline $\begin{array}{l}\text { Permanganate index } \\
\left(\mathrm{COD}_{\mathrm{Mn}}\right) / \mathrm{mg} \cdot \mathrm{L}^{-1}\end{array}$ & 2.07 & $<0.5$ & $\begin{array}{c}\text { Total iron (TFe) } \\
/ \mathrm{mg} \cdot \mathrm{L}^{-1}\end{array}$ & 0.13 & 0.012 \\
\hline
\end{tabular}

\subsection{Methods}

All experiments were conducted in controllable greenhouses at the Huixian Karst Wetland Ecological Base (Guilin, Guangxi, China). Eight liters of experimental water and $150 \mathrm{~g}$ of similarly sized E. crassipes plants with a 1:3 root to stem/leaf mass ratio were placed into individual polyethylene vessels and cultivated at $25 \pm 3{ }^{\circ} \mathrm{C}$ under natural light conditions for 24 days. The experiments were performed in triplicate with the inclusion of a control group. Deionized water was added to each experimental vessel regularly to compensate for water absorption and transpiration and keep the overall water volume constant. Figure 1 illustrates the experimental setup and Table 2 summarizes the experimental parameters. The initial $\mathrm{Pb}$ concentration in the experimental water was adjusted to $0.5 \mathrm{mg} / \mathrm{L}$. The $\mathrm{Pb}$ concentration was adjusted by adding an appropriate amount of $\mathrm{Pb}\left(\mathrm{NO}_{3}\right)_{2}$ to the experimental water. The $\mathrm{Ca}^{2+}$ concentrations in karst and non-karst water were adjusted to 60, 80, and $100 \mathrm{mg} / \mathrm{L}$, and 20 and $60 \mathrm{mg} / \mathrm{L}$, respectively. $\mathrm{Ca}^{2+}$ concentrations were adjusted by adding appropriate amounts of analytical grade $\mathrm{CaCl}_{2}$ to the experimental water. The compounds were allowed to fully dissolve before being added to the experimental vessels.

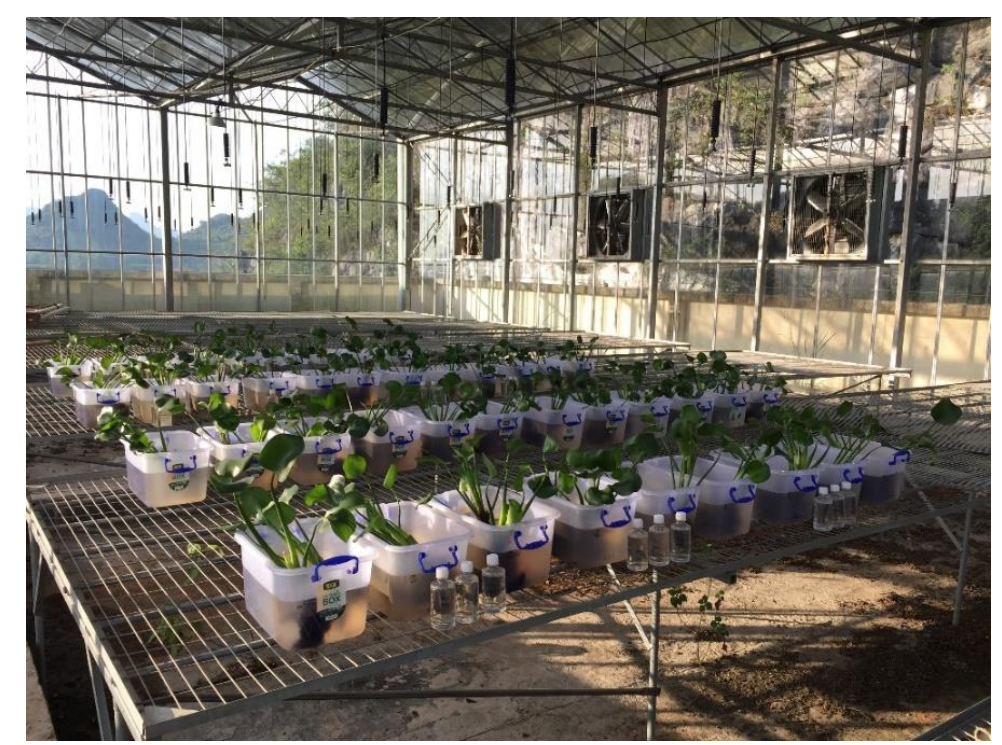

Figure 1. Experimental design. 
Table 2. Experimental parameters of the effects of calcium ion $\left(\mathrm{Ca}^{2+}\right)$ concentrations on Eichhornia crassipes absorbing lead $(\mathrm{Pb})$ in water.

\begin{tabular}{|c|c|c|c|c|c|c|c|c|}
\hline $\begin{array}{l}\text { Experimental } \\
\text { Water }\end{array}$ & $\begin{array}{l}\text { Heavy } \\
\text { Metal }\end{array}$ & Compounds & $\begin{array}{c}\text { Initial } \\
\text { Concentration } \\
\text { of } \mathrm{Pb}(\mathrm{mg} / \mathrm{L})\end{array}$ & $\begin{array}{l}\text { Volume of } \\
\text { Water (L) }\end{array}$ & $\begin{array}{c}\text { Mass of } \\
\text { Eichhornia } \\
\text { crassipes (g) }\end{array}$ & $\begin{array}{c}\text { Mass of } \\
\mathrm{Pb}\left(\mathrm{NO}_{3}\right)_{2} \\
(\mathrm{~g})\end{array}$ & $\begin{array}{c}\text { Concentration } \\
\text { of } \mathrm{Ca}^{2+} \text { in } \\
\text { Water }(\mathrm{mg} / \mathrm{L})\end{array}$ & $\begin{array}{c}\text { Mass of } \mathrm{CaCl}_{2} \\
\text { (g) }\end{array}$ \\
\hline Karst Water & $\mathrm{Pb}$ & $\mathrm{Pb}\left(\mathrm{NO}_{3}\right)_{2}$ & 0.5 & 8 & 150 & 0.0064 & $\begin{array}{c}60 \\
80 \\
100\end{array}$ & $\begin{array}{c}0 \\
0.4430 \\
0.8861\end{array}$ \\
\hline $\begin{array}{l}\text { Non-karst } \\
\text { Water }\end{array}$ & $\mathrm{Pb}$ & $\mathrm{Pb}\left(\mathrm{NO}_{3}\right)_{2}$ & 0.5 & 8 & 150 & 0.0064 & $\begin{array}{l}20 \\
60\end{array}$ & $\begin{array}{c}0 \\
0.8861\end{array}$ \\
\hline
\end{tabular}

$\mathrm{Pb}$ concentrations in water and elemental composition of E. crassipes were determined, and SEM and FTIR analyses of E. crassipes were conducted in this study. The Pb concentrations in water were tested every eight days. Polyethylene (PE) bottles were soaked in $10 \% \mathrm{HNO}_{3}$ for $24 \mathrm{~h}$ and washed three times with both deionized and the experimental water before collecting the water samples. The water samples were filtered through a $0.45-\mu \mathrm{m}$ micropore membrane filter, after which the filtrate was transferred to $50-\mathrm{mL}$ PE bottles. $\mathrm{HNO}_{3}$ was then added to reduce the water $\mathrm{pH}$ to $<2$. The $\mathrm{PE}$ bottles were then sealed with paraffin wax and stored in a $4{ }^{\circ} \mathrm{C}$ refrigerator keeping the samples from direct light contact. The $\mathrm{Pb}$ concentrations in the water samples were determined via ICP-MS (iCAP Q, Thermo Fisher Scientific, Waltham, [MA], USA) according to the GB/T 5750.6-2006. The relative standard deviation (RSD) of the measured values of each index in the water sample was below $5.0 \%$ and the standard recovery was $80-120 \%$. After the experimental treatment, E. crassipes was removed from the experimental vessel, rinsed with tap water, and allowed to dry, after which the roots, stems, and leaves were separated. The wet and dry weights of the samples were then measured. The elemental composition of roots, stems, and leaves were detected via ICP-MS according to the GB5009.268-2016. The detection limits of $\mathrm{Ca}, \mathrm{Mg}, \mathrm{Na}, \mathrm{K}, \mathrm{P}, \mathrm{Fe}, \mathrm{Mn}, \mathrm{Pb}, \mathrm{Cd}, \mathrm{Cu}$, and $\mathrm{Zn}$ were 1.00, 1.00, $1.00,1.00,1.00,1.00,0.10,0.02,0.002,0.05$, and $0.50 \mathrm{mg} / \mathrm{kg}$, respectively. The fresh roots, stems, and leaves were freeze-dried via one-step tert-butanol freeze-drying. The dried samples were sprayed with gold and the morphology of the samples was assessed via SEM (JEM-6490 LV, JEOL) at a $20 \mathrm{kV}$ accelerating voltage. The functional groups involved in the process of $\mathrm{Pb}$ absorption by E. crassipes were characterized via FTIR (Spectrum TWO, Perkin Elmer, Waltham, [MA], USA) using the KBr tablet method; $1.00 \mathrm{mg}$ of sample and $200.00 \mathrm{mg}$ of crushed $\mathrm{KBr}$ crystals were added to an agate mortar and fully ground. The mixtures were then transferred to a mold to prepare uniform and transparent ingots using a tablet press. Three ingots were prepared for each processed sample.

\subsection{Data Processing}

The experimental data were analyzed using the Origin 9 (OriginLab, Northampton, [MA], USA) Microsoft Excel 2010 (Microsoft, Redmond, [WA], USA) software, and the experimental values were expressed as the mean(s) \pm standard deviation (SD) $(n=3)$ of three replicate experiments. The data normality was first verified; descriptive statistics and data exploration were performed using the SPSS 19 software (IBM, Armonk, [NY], USA). The data were considered to be normally distributed at a $p$-value $\geq 0.05$. Afterward, variance homogeneity was verified, and mean comparisons, one-way ANOVA, and variance homogeneity were determined using SPSS 19. The variance was deemed homogeneous at a $p$-value $>0.05$. One-way ANOVA coupled with the Tukey test was performed using SPSS 19 to identify significant differences between treatments. The statistical significance threshold was set at $p<0.05$.

The results obtained in the experiments were used to determine the following parameters:

Removal rate (\%): $\mathrm{q}=\left(\mathrm{C}_{0}-\mathrm{C}\right) / \mathrm{C}_{0} \times 100 \%$;

Bioconcentration amount $(\mathrm{BCA}): \mathrm{BC}=\mathrm{CP}-\mathrm{CP}_{0}$;

Bioconcentration factor $(\mathrm{BCF}): \mathrm{BCF}=\mathrm{CP} / \mathrm{CS}$;

Translocation factor $(\mathrm{TF}): \mathrm{TF}=\mathrm{CSL} / \mathrm{CR}$, 
Where $\mathrm{C}_{0}$ is the concentration of $\mathrm{Pb}$ in water before the experiment $(\mathrm{mg} / \mathrm{L}) ; \mathrm{C}$ is the concentration of $\mathrm{Pb}$ in water during the experiment $(\mathrm{mg} / \mathrm{L}) ; \mathrm{CP}$ is the $\mathrm{Pb}$ content in a given E. crassipes structure $(\mathrm{mg} / \mathrm{kg}) ; \mathrm{CP}_{0}$ is the initial $\mathrm{Pb}$ content in a given E. crassipes structure $(\mathrm{mg} / \mathrm{kg}) ; \mathrm{CS}$ is the concentration of $\mathrm{Pb}$ in water after the experiment $(\mathrm{mg} / \mathrm{kg})$; CSL is the content of $\mathrm{Pb}$ in stems and leaves $(\mathrm{mg} / \mathrm{kg}) ; \mathrm{CR}$ is the $\mathrm{Pb}$ content in roots $(\mathrm{mg} / \mathrm{kg})$.

\section{Results and Discussion}

\subsection{Effect of $\mathrm{Ca}^{2+}$ Concentration on $\mathrm{Pb}$ Removal from Water}

As shown in Figure 2, the E. crassipes $\mathrm{Pb}$ removal rate in water varied as a function of $\mathrm{Ca}^{2+}$ concentration. The $\mathrm{Pb}$ removal rate in karst water with $60 \mathrm{mg} / \mathrm{L} \mathrm{Ca}^{2+}(85.31 \%)$ was higher than that of non-karst water with $20 \mathrm{mg} / \mathrm{L} \mathrm{Ca}^{2+}(77.04 \%)$. The $\mathrm{Pb}$ removal rate was $85.31 \%, 88.87 \%$, and $92.44 \%$ in karst water with 60,80 , and $100 \mathrm{mg} / \mathrm{L} \mathrm{Ca}^{2+}$, respectively. In non-karst water with 20 and $60 \mathrm{mg} / \mathrm{L} \mathrm{Ca}^{2+}$, the $\mathrm{Pb}$ removal rate was $77.04 \%$ and $85.24 \%$, respectively. The significant difference between the $\mathrm{Pb}$ removal rate in water with different $\mathrm{Ca}^{2+}$ concentrations was tested using SPSS 19. The $p$-value between groups was 0.004 (i.e., $<0.01$ ), indicating that the difference between the removal rates of $\mathrm{Pb}$ in water with different $\mathrm{Ca}^{2+}$ concentrations was very significant. This study found that the $\mathrm{Pb}$ removal rate increased with higher $\mathrm{Ca}^{2+}$ concentrations in both karst and non-karst water, and therefore we concluded that high $\mathrm{Ca}^{2+}$ concentrations facilitate $\mathrm{Pb}$ removal from water by E. crassipes. Calile et al. [16] demonstrated that an increased $\mathrm{Ca}^{2+}$ concentration could reduce the solubility of heavy metals in water. Yin et al. [20] analyzed the effect of liming (91\% calcium carbonate) on $\mathrm{Pb}$ weathering in sand berms and found that the total $\mathrm{Pb}$ concentrations in the limed plots were lower than those in the plots without lime. Yang et al. [21] demonstrated that $\mathrm{CaCl}_{2}$ greatly enhanced the $\mathrm{Pb}$ removal rate from blast furnace dust, which was consistent with present results. Nonetheless, $\mathrm{Pb}$ removal rates at a $60 \mathrm{mg} / \mathrm{L} \mathrm{Ca}^{2+}$ concentration were only slightly lower in non-karst water $(85.24 \%)$ than in karst water $(85.31 \%)$. It can be speculated that other hydrochemical differences (i.e., in addition to $\mathrm{Ca}^{2+}$ ) between karst and non-karst water may modulate $\mathrm{Pb}$ removal by E. crassipes, such as $\mathrm{HCO}_{3}{ }^{-}$ concentration, as proposed by Zhang et al. [19]. Therefore, the effects of $\mathrm{HCO}_{3}{ }^{-}$on $\mathrm{Pb}$ removal from karst water by E. crassipes should be analyzed in further studies.

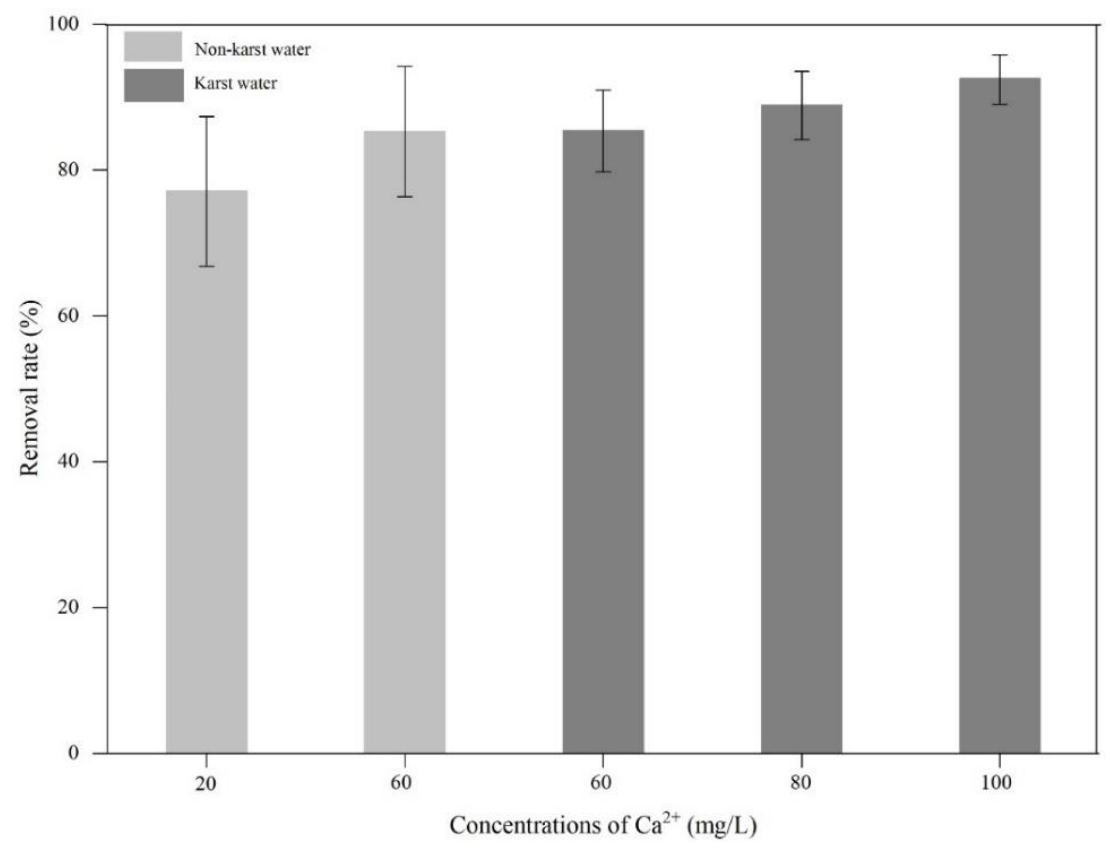

Figure 2. The removal of lead $(\mathrm{Pb})$ in water by Eichhornia crassipes under different concentrations of calcium ion $\left(\mathrm{Ca}^{2+}\right)$. 


\subsection{Effect of $\mathrm{Ca}^{2+}$ Concentration on $\mathrm{Pb}$ Absorption in E. crassipes}

The effect of $\mathrm{Ca}^{2+}$ concentration on the elemental composition of different $E$. crassipes structures before and after $\mathrm{Pb}$ absorption were tested by ICP-MS (Table 3). The Pb bioconcentration amount (BCA), bioconcentration factor (BCF), and translocation factor (TF) were then calculated (Table 4). Significant differences between the Pb BCA in E. crassipes in water with different $\mathrm{Ca}^{2+}$ concentrations were identified with the SPSS 19 software. The $p$-value was $0.001(<0.01)$, indicating that the difference between the $\mathrm{Pb}$ BCAs was very significant. The $\mathrm{Pb} B C A$ in E. crassipes roots in karst water with $60 \mathrm{mg} / \mathrm{L}$ $\mathrm{Ca}^{2+}(1763 \mathrm{mg} / \mathrm{kg})$ was lower than that in non-karst water with $20 \mathrm{mg} / \mathrm{L} \mathrm{Ca}^{2+}(2143 \mathrm{mg} / \mathrm{kg})$. The Pb BCA in E. crassipes roots in karst water with 60,80 , and $100 \mathrm{mg} / \mathrm{L} \mathrm{Ca}{ }^{2+}$ were 1763, 1317, and $1095 \mathrm{mg} / \mathrm{kg}$, respectively. Furthermore, in non-karst water with 20 and $60 \mathrm{mg} / \mathrm{L}$ of $\mathrm{Ca}^{2+}$, the $\mathrm{Pb} \mathrm{BCA}$ in E. crassipes roots was $2143 \mathrm{mg} / \mathrm{kg}$ and $1881 \mathrm{mg} / \mathrm{kg}$, respectively. This study found that Pb BCA in E. crassipes roots decreased with increased $\mathrm{Ca}^{2+}$ concentrations in both karst and non-karst water. Therefore, $\mathrm{Pb}$ removal rates from water and $\mathrm{BCA}$ in roots of $E$. crassipes exhibited opposite trends in response to $\mathrm{Ca}^{2+}$ concentration. The statistical correlations between $\mathrm{Pb} \mathrm{BCA}$ in E. crassipes and $\mathrm{Pb}$ removal rate from water as a function of $\mathrm{Ca}^{2+}$ concentration were tested via Spearman rank correlation analysis with SPSS 19. The correlation was significant at a 0.01 confidence level (bilateral). Xie [22] analyzed the effects of $\mathrm{Ca}^{2+}$ on the $\mathrm{Pb}$ stress response of Epipremnum aureum and reported that $\mathrm{Ca}^{2+}$ significantly decreased $\mathrm{Pb}$ enrichment in roots. Moreover, Shi et al. [23] reported that exogenous $\mathrm{Ca}^{2+}$ addition could significantly reduce heavy metal absorption by the roots of Wedelia trilobata. Li et al. [24] also demonstrated that $\mathrm{Ca}^{2+}$ addition significantly reduced $\mathrm{Pb}$ enrichment in Lentinus edodes, which was consistent with our results.

$\mathrm{BCF}$ is among the most important indicators of heavy metal absorption in plants. It is expressed as the ratio between the heavy metal concentrations in aquatic plant tissues to the concentration in water, whereby a $\mathrm{BCF}>1$ is indicative of heavy metal accumulation in plants [25]. The $\mathrm{Pb} \mathrm{BCF}$ in E. crassipes roots in $60 \mathrm{mg} / \mathrm{L} \mathrm{Ca}^{2+}$ karst water $(30,306)$ was higher than that in non-karst water with $20 \mathrm{mg} / \mathrm{L} \mathrm{Ca}^{2+}(21,583)$, which was consistent with the $\mathrm{Pb}$ removal rate in water. The highest $\mathrm{Pb} \mathrm{BCF}$ $(31,531)$ was observed in $80 \mathrm{mg} / \mathrm{L} \mathrm{Ca}^{2+}$ karst water. The Pb BCF in E. crassipes roots in $60 \mathrm{mg} / \mathrm{L} \mathrm{Ca}^{2+}$ non-karst water $(35,186)$ was higher than that in $20 \mathrm{mg} / \mathrm{L} \mathrm{Ca}^{2+}$ non-karst water.

TF represents the ability of plants to transfer the absorbed heavy metals from underground to aboveground structures. A TF value $>1$ indicates that the plant has a strong ability to transport a certain heavy metal [26]. The $\mathrm{Pb}$ TF in E. crassipes in water with different $\mathrm{Ca}^{2+}$ concentrations was below 1 , indicating that the $\mathrm{Pb}$ transport ability of E. crassipes was weak regardless of $\mathrm{Ca}^{2+}$ concentration. High $\mathrm{Ca}^{2+}$ concentrations in water had no significant effect on the ability of E. crassipes to transfer $\mathrm{Pb}$ from roots to stems and leaves. E. crassipes has the ability to protect leaves and stems from the toxic effects of $\mathrm{Pb}$ on photosynthesis. Plants commonly absorb harmful heavy metals into their roots as a defense mechanism to prevent toxicity to leaves and stems and to maintain photosynthesis and other metabolic activities [27,28]. The lowest $\mathrm{Pb} \mathrm{TF}$ occurred in $80 \mathrm{mg} / \mathrm{L} \mathrm{Ca}^{2+}$ karst water $(0.0650)$. The $\mathrm{Pb}$ TF in E. crassipes in $60 \mathrm{mg} / \mathrm{L} \mathrm{Ca}^{2+}$ non-karst water $(0.211)$ was lower than that in non-karst water with $20 \mathrm{mg} / \mathrm{L} \mathrm{Ca}^{2+}$ (0.256). A similar study reported that certain $\mathrm{Ca}^{2+}$ concentrations could inhibit the transport of heavy metals from underground to aboveground plant structures [15]. 
Table 3. Elemental composition of different E. crassipes structures before and after $\mathrm{Pb}$ absorption in water with different $\mathrm{Ca}^{2+}$ concentrations (mg/kg).

\begin{tabular}{|c|c|c|c|c|c|c|c|c|c|c|c|c|c|}
\hline $\begin{array}{l}\text { Water } \\
\text { Body }\end{array}$ & $\begin{array}{c}\text { Concentrations of } \mathrm{Ca}^{2+} \\
\text { in Water }(\mathrm{mg} / \mathrm{L})\end{array}$ & Parts & $\mathrm{Ca}$ & $\mathrm{Mg}$ & $\mathbf{K}$ & $\mathrm{Na}$ & $\mathbf{P}$ & $\mathrm{Fe}$ & Mn & $\mathrm{Pb}$ & Cd & $\mathrm{Cu}$ & $\mathrm{Zn}$ \\
\hline \multirow{7}{*}{$\begin{array}{l}\text { Karst } \\
\text { Water }\end{array}$} & \multirow[b]{2}{*}{60} & Roots & 13,401 & 1157 & 3021 & 690 & 2529 & 15,036 & 2320 & 1771 & 0.448 & 14.8 & 212 \\
\hline & & Stems and Leaves & 17,800 & 1251 & 15,301 & 663 & 2932 & 2895 & 302 & 177 & 0.0933 & 177 & 77.8 \\
\hline & \multirow{3}{*}{80} & Roots & 13,555 & 684 & 1703 & 581 & 1941 & 7351 & 1537 & 1324 & 0.520 & 9.47 & 155 \\
\hline & & Stems and Leaves & 20,600 & 1294 & 10,938 & 612 & 3287 & 491 & 225 & 86.5 & 0.134 & 31.4 & 45.0 \\
\hline & & Whole Plant & 18,839 & 1142 & 8629 & 604 & 2950 & 2206 & 553 & 396 & 0.230 & 25.9 & 72.5 \\
\hline & \multirow[t]{2}{*}{100} & Stems and Leaves & 22,100 & 905 & 6181 & 610 & 3196 & 770 & 300 & 173 & 0.109 & 37.2 & 52.7 \\
\hline & & Whole Plant & 20,567 & 813 & 5020 & 596 & 2940 & 1839 & 447 & 406 & 0.144 & 30.1 & 69.3 \\
\hline \multirow{6}{*}{$\begin{array}{l}\text { Non-karst } \\
\text { Water }\end{array}$} & \multirow{3}{*}{60} & Roots & 12,610 & 671 & 2173 & 574 & 1903 & 9183 & 2180 & 1888 & 0.331 & 13.3 & 220 \\
\hline & & Stems and Leaves & 20,900 & 1086 & 13,391 & 651 & 3250 & 964 & 361 & 398 & 0.133 & 38.2 & 57.4 \\
\hline & & Whole Plant & 18,828 & 982 & 10,586 & 632 & 2913 & 3019 & 816 & 770 & 0.182 & 32.0 & 98.0 \\
\hline & \multirow{3}{*}{20} & Roots & 13,316 & 576 & 1608 & 557 & 1859 & 3801 & 838 & 2151 & 0.204 & 9.70 & 108 \\
\hline & & Stems and Leaves & 17,600 & 1217 & 14,594 & 610 & 2809 & 574 & 308 & 550 & 0.0860 & 32.3 & 34.3 \\
\hline & & Whole Plant & 16,529 & 1057 & 11,348 & 597 & 2572 & 1381 & 440 & 950 & 0.116 & 26.6 & 52.7 \\
\hline \multirow{2}{*}{\multicolumn{2}{|c|}{ Unloaded }} & Stems and Leaves & 15,500 & 1700 & 32,800 & 830 & 2900 & 279 & 192 & 0.730 & 0.0370 & 18.9 & 38.7 \\
\hline & & Whole Plant & 13,275 & 2325 & 28,950 & 1198 & 2675 & 2570 & 598 & 2.46 & 0.118 & 16.5 & 53.6 \\
\hline
\end{tabular}


Table 4. Enrichment of $\mathrm{Pb}$ in different E. crassipes structures in water with different $\mathrm{Ca}^{2+}$ concentrations.

\begin{tabular}{|c|c|c|c|c|c|c|c|}
\hline Water Body & $\begin{array}{c}\text { Concentrations of } \\
\mathrm{Ca}^{2+} \text { in Water } \\
(\mathrm{mg} / \mathrm{L})\end{array}$ & $\begin{array}{c}\text { Concentration of } \mathrm{Pb} \text { in } \\
\text { Water After the } \\
\text { Experiment }(\mathrm{mg} / \mathrm{kg})\end{array}$ & $\begin{array}{c}\text { Removal Rate } \\
(\%)\end{array}$ & Parts & BCA (mg/kg) & BCF & TF \\
\hline \multirow{7}{*}{$\begin{array}{l}\text { Karst } \\
\text { Water }\end{array}$} & \multirow{2}{*}{60} & \multirow{2}{*}{$0.058 \pm 0.018$} & \multirow{2}{*}{$85.31 \pm 5.61$} & Roots & 1763 & 30,360 & 1 \\
\hline & & & & Whole Plant & 576 & 9866 & 0.100 \\
\hline & \multirow[b]{2}{*}{80} & \multirow[b]{2}{*}{$0.042 \pm 0.013$} & \multirow[b]{2}{*}{$88.87 \pm 4.68$} & Roots & 1317 & 31,531 & 1 \\
\hline & & & & Stems and Leaves & 85.7 & 2059 & 1 \\
\hline & \multirow{3}{*}{100} & \multirow{3}{*}{$0.038 \pm 0.015$} & \multirow{3}{*}{$92.44 \pm 3.40$} & Roots & 1095 & 28,761 & 1 \\
\hline & & & & Stems and Leaves & 173 & 4523 & 1 \\
\hline & & & & Whole Plant & 406 & 10,578 & 0.157 \\
\hline \multirow{3}{*}{$\begin{array}{l}\text { Non-karst } \\
\text { Water }\end{array}$} & \multirow{3}{*}{60} & \multirow{3}{*}{$0.054 \pm 0.019$} & \multirow{3}{*}{$85.24 \pm 8.91$} & Roots & 1881 & 35,186 & 1 \\
\hline & & & & Stems and Leaves & 398 & 7424 & 1 \\
\hline & & & & Whole Plant & 770 & 14,357 & 0.211 \\
\hline
\end{tabular}

\subsection{Morphology Analysis}

The morphology of roots, stems, and leaves of E. crassipes in water was examined by SEM. The SEM images of roots, stems, and leaves of E. crassipes in 60 and $80 \mathrm{mg} / \mathrm{L} \mathrm{Ca}^{2+}$ karst water are illustrated in Figure 3.
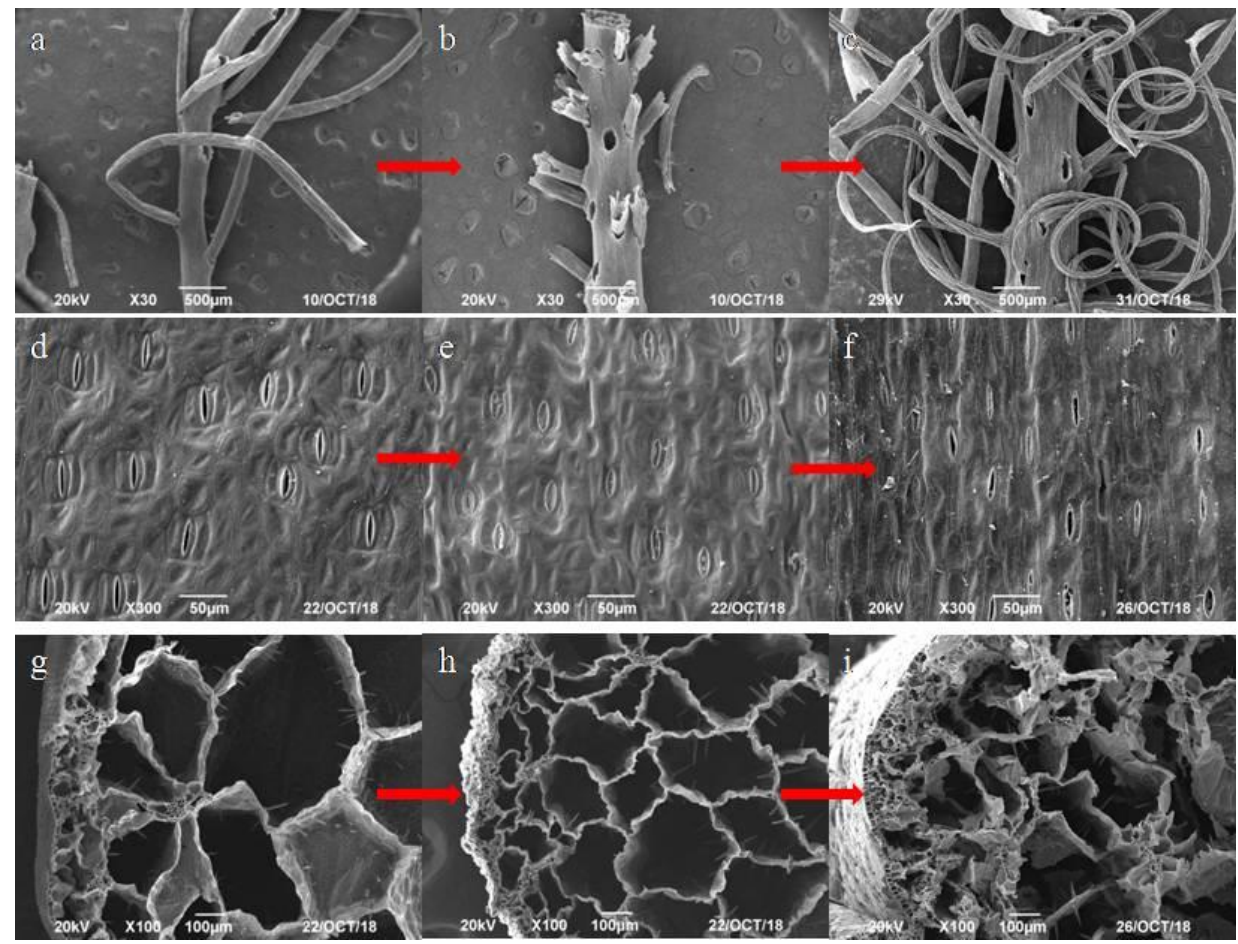

Figure 3. SEM images of (a) roots before experiment, (b) roots in karst water with $60 \mathrm{mg} / \mathrm{L} \mathrm{Ca}^{2+}$, (c) roots in karst water with $80 \mathrm{mg} / \mathrm{L} \mathrm{Ca}^{2+}$, (d) leaves before experiment, (e) leaves in karst water with 60 $\mathrm{mg} / \mathrm{L} \mathrm{Ca}^{2+}$, (f) leaves in karst water with $80 \mathrm{mg} / \mathrm{L} \mathrm{Ca}^{2+}$,(g) stems before experiment, (h) stems in karst water with $60 \mathrm{mg} / \mathrm{L} \mathrm{Ca}^{2+}$, (i) stems in karst water with $80 \mathrm{mg} / \mathrm{L} \mathrm{Ca}^{2+}$.

Roots are vital structures for plant growth, as they are mainly responsible for absorbing water and inorganic salts. The root system is comprised of taproots and fibrous roots, which are largely responsible for pollutant removal. Figure 3a shows that there are voids between the taproots and fibrous roots of E. crassipes. Many of these voids develop into air passages, which provide buoyancy, support, and favorable conditions for roots to absorb heavy metals and enhance the adaptability of $E$. 
crassipes to aquatic environments. The cell walls of roots act as a biological semipermeable membrane, which is difficult for large molecular weight substances, nonionic compounds, and colloids to penetrate. There is also a large contact area between the root system and the water surface, which forms a filter layer capable of absorbing a variety of heavy metals to improve water quality [8,29]. As shown in Figure $3 b, c$, the voids between the taproots and fibrous roots did not change significantly in karst water with 60 and $80 \mathrm{mg} / \mathrm{L} \mathrm{Ca}^{2+}$. Moreover, fibrous roots were more fragile in karst water with $60 \mathrm{mg} / \mathrm{L}$ than in karst water with $80 \mathrm{mg} / \mathrm{L} \mathrm{Ca}^{2+}$. This study demonstrated that $\mathrm{Pb}$ had low toxicity on $E$. crassipes roots, which was attributable to the high $\mathrm{Ca}^{2+}$ concentrations in karst water. Similar studies also showed that high concentrations of $\mathrm{Ca}^{2+}$ could reduce the toxicity of heavy metals to other plants $[23,24]$.

Leaves are important plant structures that are responsible for photosynthesis, gas exchange, and transpiration. Leaves have a relatively large surface area and contain many stomas, distributed evenly on the epidermis. Figure 3d illustrates the highly developed stoma structure of E. crassipes leaves, which enhances the photosynthesis and transpiration capacity of E. crassipes and promotes a more efficient heavy metal absorption in water through the roots. As shown in Figure 3e, most stomas were closed after absorbing $\mathrm{Pb}$ in $60 \mathrm{mg} / \mathrm{L} \mathrm{Ca}^{2+}$ karst water. A similar study reported that E. crassipes possesses many small stomas, which closed upon safranin exposure [30]. Heavy metals enter leaves through the open stomas and then compromise the physiological activities of plants [31]. Brunet et al. [32] demonstrated that heavy metals disrupted carbon sequestration, which was attributed to stomatal closure. As shown in Figure 3f, when the $\mathrm{Ca}^{2+}$ concentration was $80 \mathrm{mg} / \mathrm{L}$ in karst water, a few stomas were still open. Therefore, our results suggest that $\mathrm{Pb}$ seriously damaged leaf morphology and high $\mathrm{Ca}^{2+}$ concentrations in karst water alleviated this $\mathrm{Pb}$-induced morphological damage.

Stems are comprised of a highly developed intercellular epidermis, spongy cortex, vascular bundles, and medulla; the vascular bundle is arranged as a ring around the medulla, forming a complex network. As shown in Figure 3g, these structures are comprised of many interconnected air chambers and different sized airways, which facilitate gas exchange and storage. As shown in Figure $3 \mathrm{~h}$, after absorbing $\mathrm{Pb}$ in $60 \mathrm{mg} / \mathrm{L} \mathrm{Ca}^{2+}$ karst water, the cortex became atrophied and thin, and the volume of the annular vascular bundle structure decreased. As shown in Figure 3i, the cortical morphology of stems was less affected in $80 \mathrm{mg} / \mathrm{L} \mathrm{Ca}^{2+}$ karst water. These results suggest that $E$. crassipes stems were seriously damaged by $\mathrm{Pb}$; however, the high concentration of $\mathrm{Ca}^{2+}$ in karst water reduced the $\mathrm{Pb}$-induced morphological effects in stems.

The voids in roots, leaf stomas, air chambers, and stem airways provided favorable conditions for E. crassipes to accumulate large amounts of $\mathrm{Pb}$. The morphology of stems and leaves was damaged more seriously than that of roots after absorbing $\mathrm{Pb}$, indicating that roots had a stronger tolerance to $\mathrm{Pb}$ than stems and leaves. The results of this study demonstrate that roots were the main E. crassipes structures responsible for $\mathrm{Pb}$ absorption. Moreover, increased $\mathrm{Ca}^{2+}$ concentrations in water led to a reduction in $\mathrm{Pb}$-induced damage to roots, stems, and leaves, thereby enhancing the adaptability of $E$. crassipes to Pb stress.

\subsection{Functional Group Analysis}

Figure 4 illustrates the transmittance spectrum of E. crassipes roots before and after absorbing $\mathrm{Pb}$ in water with different $\mathrm{Ca}^{2+}$ concentrations. FTIR spectra can provide a wealth of useful information on functional groups [33]. As shown in Figure 4, the FTIR spectrum of E. crassipes roots exhibited a few intense bands associated with organic functional groups. The broad band observed at 3453 $\mathrm{cm}^{-1}$ was attributed to $\mathrm{O}-\mathrm{H}$ stretching vibration. The spectra peak at $2927 \mathrm{~cm}^{-1}$ represented $-\mathrm{CH}_{3}$ stretching vibration. The spectrum band observed at $2347 \mathrm{~cm}^{-1}$ reflected $C \equiv C$ stretching vibration. The spectra peak at $1651 \mathrm{~cm}^{-1}$ represented protein $\mathrm{C}=\mathrm{O}$ stretching vibration. The spectra band observed at $1033 \mathrm{~cm}^{-1}$ reflected C-O stretching vibration. The spectra peak at $534 \mathrm{~cm}^{-1}$ was attributed to $\mathrm{SO}_{4}{ }^{2-}$ stretching vibration [34]. 


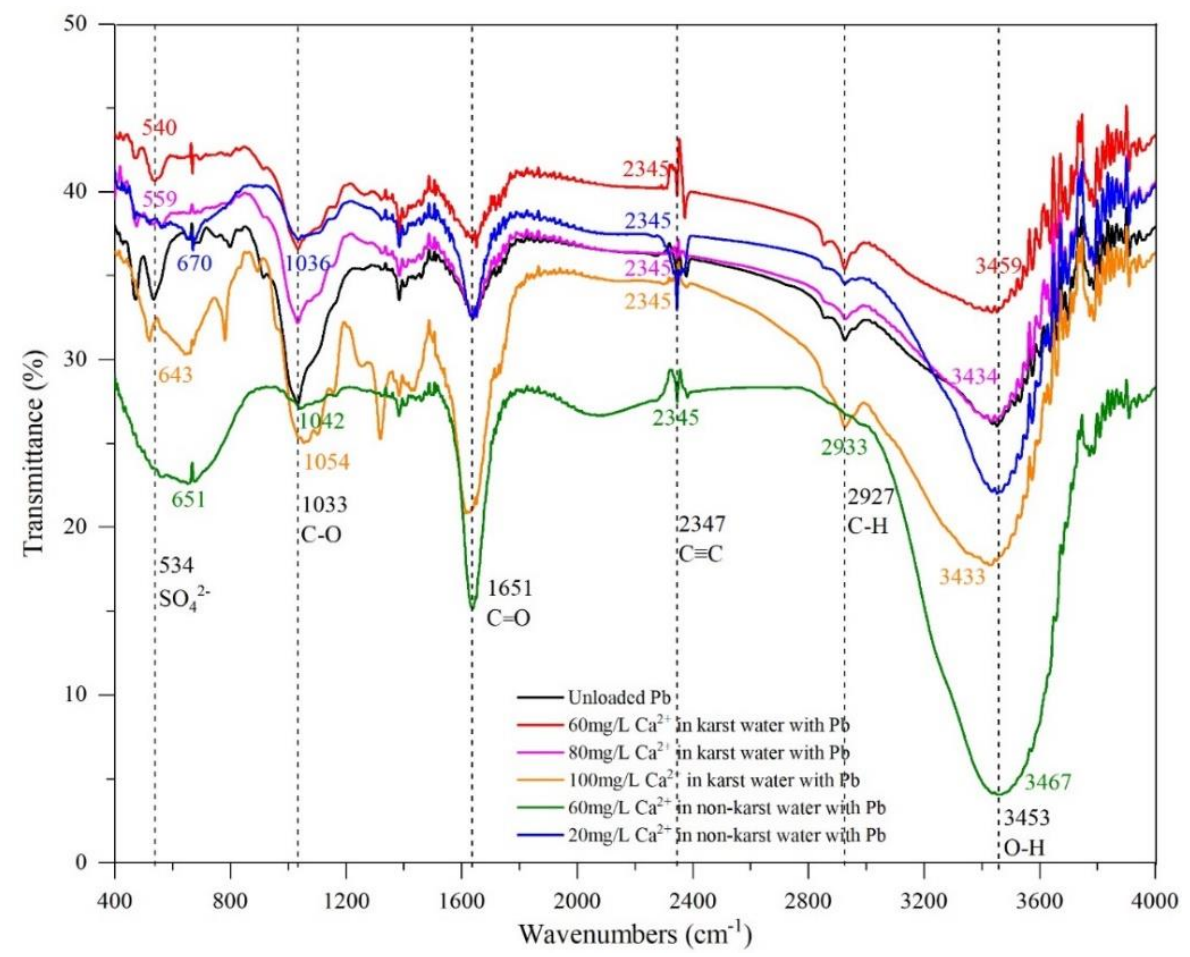

Figure 4. Transmittance spectrum of E. crassipes roots before and after absorbing $\mathrm{Pb}$ in water with different $\mathrm{Ca}^{2+}$ concentrations.

As shown in Figure 4, both $C \equiv C$ peaks shifted from 2347 to $2345 \mathrm{~cm}^{-1}$, and the peak strength of $\mathrm{C} \equiv \mathrm{C}$ in karst water with $60 \mathrm{mg} / \mathrm{L} \mathrm{Ca}^{2+}$ was smaller than that in non-karst water with $20 \mathrm{mg} / \mathrm{L} \mathrm{Ca}^{2+}$. The protein $\mathrm{C}=\mathrm{O}$ peak on the cell walls at $1651 \mathrm{~cm}^{-1}$ did not shift, but the peak strength in karst water was greater than that in non-karst water, indicating that the cell wall structure changed when the protein $\mathrm{C}=\mathrm{O}$ interacted with $\mathrm{Pb}$ [35]. The $\mathrm{SO}_{4}{ }^{2-}$ peak at $534 \mathrm{~cm}^{-1}$ shifted to $540 \mathrm{~cm}^{-1}$ in karst water but shifted to $670 \mathrm{~cm}^{-1}$ in non-karst water. The peak strength of the $\mathrm{SO}_{4}{ }^{2-}$ stretching vibration in karst water was greater than that in non-karst water. Therefore, this study demonstrated that $\mathrm{C} \equiv \mathrm{C}$, protein $\mathrm{C}=\mathrm{O}$, and $\mathrm{SO}_{4}{ }^{2-}$ played different roles in karst and non-karst water. $\mathrm{O}-\mathrm{H}$ only had an effect in karst water, and the $\mathrm{O}-\mathrm{H}$ peak shifted from 3453 to $3459 \mathrm{~cm}^{-1}$. The C-O peak only reacted in non-karst water, where it shifted from 1033 to $1036 \mathrm{~cm}^{-1}$. It is speculated that the different hydrochemical characteristics of karst and non-karst water may lead to the observed differences in functional groups, spectrum shapes, and the displacement and strength of some peaks, which should be examined in future research.

No significant changes in FTIR spectra shape were observed in karst water with 60, 80, and 100 $\mathrm{mg} / \mathrm{L} \mathrm{Ca}^{2+}$, suggesting that high $\mathrm{Ca}^{2+}$ concentrations in karst water did not obviously change the basic chemical composition of roots. Li [36] reported similar results in E. crassipes exposed to heavy metals in polluted aquatic environments. However, the displacement and strength of some peaks changed. The O-H peaks at $3453 \mathrm{~cm}^{-1}$ shifted to 3459,3434 , and $3433 \mathrm{~cm}^{-1}$ in karst water with 60,80 , and $100 \mathrm{mg} / \mathrm{L}$ $\mathrm{Ca}^{2+}$, respectively. Moreover, the O-H peak strength increased with increased $\mathrm{Ca}^{2+}$ concentrations, indicating that $\mathrm{Ca}^{2+}$ concentrations in karst water increased the occurrence of hydroxyl hydrogen bonds on the surface of $E$. crassipes. The $\mathrm{C} \equiv \mathrm{C}$ peak at $2347 \mathrm{~cm}^{-1}$ had a same displacement, but the peak strength decreased with increased $\mathrm{Ca}^{2+}$ concentrations, suggesting that the strength of alkynyl groups on the surface of E. crassipes weakened as a result of combining $\mathrm{Pb}$ with the high $\mathrm{Ca}^{2+}$ concentrations in karst water. Acetylene compounds are easily oxidized; however, higher $\mathrm{Ca}^{2+}$ concentrations in karst water reduced the oxidization of the acetylene bond of alkynyl. The protein $\mathrm{C}=\mathrm{O}$ peak at $1651 \mathrm{~cm}^{-1}$ did not shift, but the peak strength increased with higher $\mathrm{Ca}^{2+}$ concentrations, suggesting that cell wall structure changed when exposed to $\mathrm{Pb}$. This result was consistent with a previous study that compared infrared spectroscopy between endogenous and exogenous metals in phytoplankton [37]. 
Protein $\mathrm{C}=\mathrm{O}$ bonds played a more important role during $\mathrm{Pb}$ exposure. Cells absorb heavy metal ions through extracellular space, and the cell walls of plants are the first barrier against pollutants. The polyuronic acid and cellulose in cell walls provide a large number of exchange sites for pollutants [38]. $\mathrm{Pb}$ has a notably large ion radius and weak coordination ability. Therefore, it is difficult for $\mathrm{Pb}$ to enter into the cytoplasm through the cell wall and plasma membrane. E. crassipes absorbs $\mathrm{Pb}$ mainly through cell walls, as well as through non-metabolic interstitial diffusion between cells. $\mathrm{Pb}$ begins to enter the cytoplasm through the cell walls and plasma membranes after reaching saturation, and the toxicity of $\mathrm{Pb}$ to E. crassipes is low when the absorption speed is fast [39]. The peak strength of $\mathrm{SO}_{4}{ }^{2-}$ at 534 $\mathrm{cm}^{-1}$ shifted to 540,559 , and $643 \mathrm{~cm}^{-1}$ in karst water with 60,80 , and $100 \mathrm{mg} / \mathrm{L} \mathrm{Ca}{ }^{2+}$, respectively. The increased $\mathrm{SO}_{4}{ }^{2-}$ displacement indicated the presence of a small amount of sulfuric acid in E. crassipes. $\mathrm{SO}_{4}{ }^{2-}$ played a more significant role with increased $\mathrm{Ca}^{2+}$ concentrations. This study showed that when the $\mathrm{Ca}^{2+}$ concentration increased from 60 to $80 \mathrm{mg} / \mathrm{L}, \mathrm{O}-\mathrm{H}, \mathrm{C} \equiv \mathrm{C}$, protein $\mathrm{C}=\mathrm{O}$, and $\mathrm{SO}_{4}{ }^{2-}$ responded to $\mathrm{Pb}$ exposure. When the $\mathrm{Ca}^{2+}$ concentration increased to $100 \mathrm{mg} / \mathrm{L}$, a new functional group (C-O) at $1033 \mathrm{~cm}^{-1}$ was identified. The occurrence of $\mathrm{O}-\mathrm{H}$ at $3453 \mathrm{~cm}^{-1}$ and $\mathrm{C}-\mathrm{O}$ at $1033 \mathrm{~cm}^{-1}$ proved that E. crassipes contains alcoholic hydroxyl groups. Alcohol compounds are easily oxidized [34]. In this study, the results showed that alcoholic hydroxyls played a more significant role in karst water with high $\mathrm{Ca}^{2+}$ concentrations.

Our results suggest that high $\mathrm{Ca}^{2+}$ concentrations play an important role in regulating the response of functional groups in E. crassipes during $\mathrm{Pb}$ exposure. Some organic compounds such as alcohol and sulfate resins are known to be present in E. crassipes and both alcoholic hydroxyls and $\mathrm{SO}_{4}{ }^{2-}$ play a more significant role in water with high $\mathrm{Ca}^{2+}$ concentrations. Increases in $\mathrm{Ca}^{2+}$ concentrations in water reduce the oxidization of alkynyl acetylene bonds and therefore protect the cell of E. crassipes form heavy metal-induced damage.

\subsection{Ion Exchange Analysis}

Figure 5 illustrates the elemental composition and distribution in E. crassipes roots before and after $\mathrm{Pb}$ absorption from water with different $\mathrm{Ca}^{2+}$ concentrations. As shown in Figure 5 , the $\mathrm{Pb}$ and $\mathrm{Ca}$ content in E. crassipes roots increased after absorbing the waterborne $\mathrm{Pb}$. In contrast, the $\mathrm{Mg}, \mathrm{Na}$, and $\mathrm{K}$ contents in E. crassipes roots decreased. These observations are suggestive of cation exchange, whereby $\mathrm{Pb}$ was exchanged for $\mathrm{Mg}$, $\mathrm{Na}$, and $\mathrm{K}$ during the process of $\mathrm{Pb}$ absorption form water. Li et al. [34] demonstrated that $\mathrm{Ca}, \mathrm{Mg}$, and $\mathrm{K}$ were depleted from E. crassipes roots, while $\mathrm{Cu}$ and $\mathrm{Cr}$ were accumulated upon $\mathrm{Pb}$ exposure. Xia [40] also demonstrated that $\mathrm{Pb}$ was exchanged for $\mathrm{K}$, $\mathrm{Ca}$, and $\mathrm{Mg}$ during the absorption of $\mathrm{Pb}$ by E. crassipes, which was consistent with our results. The absorption of $\mathrm{Ca}$ and the depletion of $\mathrm{Mg}, \mathrm{Na}$, and $\mathrm{K}$ was more pronounced in E. crassipes roots when the $\mathrm{Ca}^{2+}$ concentrations in karst water were higher, indicating that high $\mathrm{Ca}^{2+}$ concentrations stimulated cation exchange. Furthermore, Na: K proportions in E. crassipes roots $(0.228,0.341$, and 0.362$)$ and Ca: $\mathrm{Mg}$ proportions $\left(11.6,19.8\right.$, and 29.8) increased in roots with increased $\mathrm{Ca}^{2+}$ concentrations in karst water $(60,80$, and $100 \mathrm{mg} / \mathrm{L})$. 


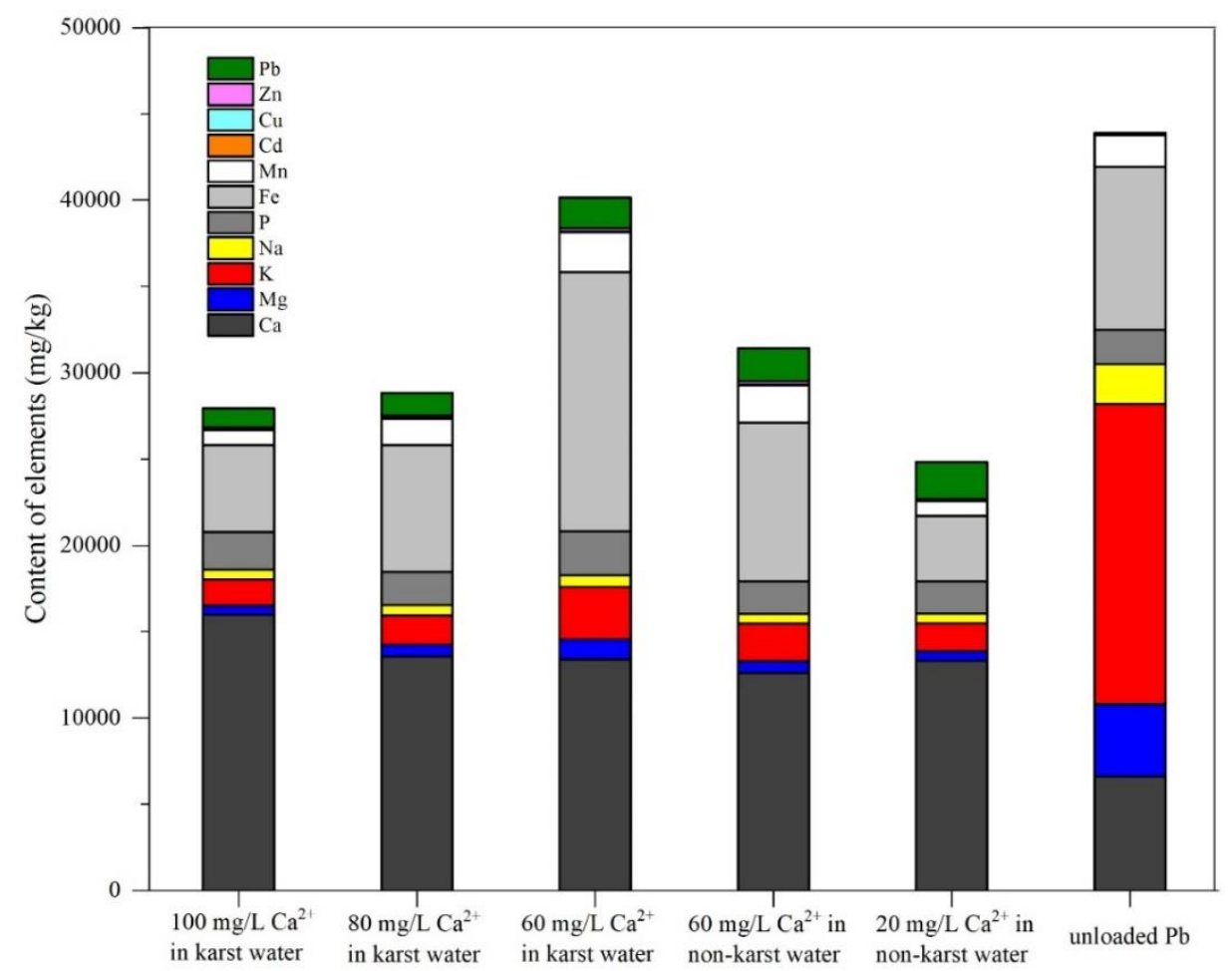

Figure 5. Elemental composition and distribution in E. crassipes roots before and after $\mathrm{Pb}$ absorption from water with different $\mathrm{Ca}^{2+}$ concentrations.

\subsection{Elemental Biogeochemical Behavior}

Plants are selective in absorbing elements. Generally, plants absorb elements that are richer, easier to obtain, and that can serve a particular function. $\mathrm{Ca}$ is an essential element for plants. It is also an important plant growth regulator and mediates the response to environmental changes [11]. $\mathrm{Pb}$ is a nonessential trace element that occurs in nature; however, its accumulation can lead to serious toxic effects. $\mathrm{Pb}$ accumulation in plants mainly affects photosynthesis and transpiration. In our study, higher $\mathrm{Ca}^{2+}$ concentrations in the water led to decreased $\mathrm{Pb} \mathrm{BCA}$ and higher $\mathrm{Ca}$ absorption in E. crassipes roots (Table 3). These results suggest that there was a competitive relationship between $\mathrm{Ca}$ and $\mathrm{Pb}$ in the process of being absorbed by E. crassipes. High $\mathrm{Ca}^{2+}$ concentrations in water therefore inhibited the absorption of $\mathrm{Pb}$.

$\mathrm{Pb}$ concentration and form in natural water are affected by the concentrations of $\mathrm{CO}_{3}{ }^{2-}, \mathrm{SO}_{4}{ }^{2-}$, and $\mathrm{OH}^{-}$, which facilitate the precipitation of $\mathrm{Pb}$ into $\mathrm{PbCO}_{3}, \mathrm{PbSO}_{4}$, and $\mathrm{Pb}(\mathrm{OH})_{2}$. The concentration of $\mathrm{Pb}$ in water is controlled by hydroxide ions, and the main complexation reactions in natural waters can be described as follows:

$$
\begin{aligned}
\mathrm{Pb}^{2+}+\mathrm{OH}^{-} & =\mathrm{PbOH}^{+} \\
\mathrm{Pb}^{2+}+2 \mathrm{OH}^{-} & =\mathrm{Pb}(\mathrm{OH})_{2}^{0} \\
\mathrm{~Pb}^{2+}+3 \mathrm{OH}^{-} & =\mathrm{Pb}(\mathrm{OH})_{3}^{-} \\
\mathrm{Pb}^{2+}+\mathrm{Cl}^{-} & =\mathrm{PbCl}^{+} \\
\mathrm{Pb}^{2+}+2 \mathrm{Cl}^{-} & =\mathrm{Pb}(\mathrm{Cl})_{2}^{0}
\end{aligned}
$$

When the $\mathrm{pH}$ of water is 8.5 , the proportions of $\mathrm{Pb}$ complexes are typically $88 \% \mathrm{PbOH}^{+}, 10 \%$ $\mathrm{PbCO}_{3}$, and $2 \%\left(\mathrm{PbCl}^{+}+\mathrm{PbSO}_{4}\right)$ [41]. $\mathrm{OH}^{-}$and $\mathrm{CO}_{3}{ }^{2-}$ can form ion pairs with $\mathrm{Ca}^{2+}$, but this mainly occurs in strongly alkaline solutions $(\mathrm{pH}>9.5)$. The $\mathrm{pH}$ of karst water used in our experiments was 7.25 and $\mathrm{pH}$ varied between 8.27 and 8.60 as the $\mathrm{Ca}^{2+}$ concentration increased. The $\mathrm{pH}$ of natural water mainly depends on its free carbon dioxide $\left(\mathrm{CO}_{2}\right)$ content and carbonate equilibrium. $E$. 
crassipes absorbs a substantial amount of $\mathrm{CO}_{2}$ during photosynthesis and $\mathrm{pH}$ likely increased due to photosynthesis-linked $\mathrm{CO}_{2}$ uptake. $\mathrm{OH}^{-}$tended to form complexes with $\mathrm{Pb}$ rather than with $\mathrm{Ca}^{2+}$ due to the increase of $\mathrm{pH}$ in water. Some of the dissolved $\mathrm{Pb}$ existed in the form of $\mathrm{PbOH}^{+}, \mathrm{PbCO}_{3}, \mathrm{PbCl}^{+}$, and $\mathrm{PbSO}_{4}$. However, the solubility and mobility of $\mathrm{Pb}$ decreased because $\mathrm{PbCO}_{3}$ and $\mathrm{PbSO}_{4}$ are insoluble in water, which affected the absorption of $\mathrm{Pb}$ by E. crassipes. As the $\mathrm{pH}$ of the water increased with the increase of $\mathrm{Ca}^{2+}$ concentrations, $\mathrm{PbCO}_{3}$ and $\mathrm{PbSO}_{4}$ became more abundant.

As a result of increased $\mathrm{Ca}^{2+}$ concentrations, the precipitation of $\mathrm{PbCO}_{3}$ and $\mathrm{PbSO}_{4}$ and the competitive relationship between $\mathrm{Ca}$ and $\mathrm{Pb}$ in water led to a decrease in $\mathrm{Pb} \mathrm{BCA}$ in E. crassipes and a higher $\mathrm{Pb}$ removal rate from water. Moreover, high $\mathrm{Ca}^{2+}$ concentrations alleviated the $\mathrm{Pb}$-induced morphological damage to roots, stems, and leaves.

\section{Conclusions}

In summary, high $\mathrm{Ca}^{2+}$ concentrations improved the $\mathrm{Pb}$ removal efficiency of E. crassipes in karst water, but reduced the $\mathrm{Pb} \mathrm{BCA}$ in E. crassipes roots. In contrast, the Ca BCA in roots increased, with increased $\mathrm{Ca}^{2+}$ concentrations in karst water. The highest bioconcentration factor and the lowest transport factor of $\mathrm{Pb}$ occurred in $80 \mathrm{mg} / \mathrm{L} \mathrm{Ca}^{2+}$ karst water. The differences in bioconcentration amounts and removal rates induced by higher $\mathrm{Ca}^{2+}$ concentrations were attributed to $\mathrm{Pb}$ precipitation (i.e., as $\mathrm{PbCO}_{3}$ and $\mathrm{PbSO}_{4}$ ) and the competitive relationship between $\mathrm{Ca}$ and $\mathrm{Pb}$ in karst water. High $\mathrm{Ca}^{2+}$ concentrations in karst water increased the strength of cation exchange, whereby $\mathrm{Pb}$ was exchanged for $\mathrm{Mg}, \mathrm{Na}$, and $\mathrm{K}$. Moreover, high $\mathrm{Ca}^{2+}$ concentrations in karst water alleviated $\mathrm{Pb}$-induced structural damage to roots, stems, and leaves, and protected the cell wall of E. crassipes. $\mathrm{Ca}^{2+}$ also regulated the functional groups involved during $\mathrm{Pb}$ exposure in E. crassipes. The oxidization of alkynyl acetylene bonds decreased, and alcohol compounds and sulfate resin were both important during $\mathrm{Pb}$ pressing in water with high $\mathrm{Ca}^{2+}$ concentrations. Therefore, increasing the supply of $\mathrm{Ca}^{2+}$ could reduce the uptake of $\mathrm{Pb}$ and alleviate $\mathrm{Pb}$ toxicity in E. crassipes.

Author Contributions: Conceptualization, J.Z. and Z.J.; Methodology, J.Z.; Software, J.Z.; Validation, J.Z., Z.J., and L.Z.; Formal Analysis, J.Z.; Investigation, J.Z.; Resources, Z.J., X.Q., and Q.H.; Data Curation, J.Z.; Writing-Original Draft Preparation, J.Z.; Writing - Review \& Editing, J.Z., Z.J., and L.Z.; Visualization, J.Z.; Supervision, J.Z., Z.J., and G.X. All authors have read and agreed to the published version of the manuscript.

Funding: This work was supported by the National Natural Science Foundation of China (41571203), the Basic Scientific Research Operating Expenses Project of the Chinese Academy of Geological Sciences (YYWF201725), the China Geological Survey's Project (DD20190343), and the China Scholarship Council (CSC) (No. 201908110325).

Conflicts of Interest: The authors declare no potential conflict of interest.

\section{References}

1. Wu, L.; Liu, G.J.; Zhou, C.C.; Liu, R.Q.; Xi, S.S.; Da, C.N.; Liu, F. Spatial distributions, fractionation characteristics, and ecological risk assessment of trace elements in sediments of Chaohu Lake, a large eutrophic freshwater lake in eastern China. Environ. Sci. Pollut. Res. 2018, 25, 588-600. [CrossRef]

2. Zhou, J.M.; Jiang, Z.C.; Xu, G.L.; Qin, X.Q.; Huang, Q.B.; Zhang, L.K. Major Ionic Characteristics and Controlling Factors of Karst Groundwater at Xiangshui, Chongzuo. Environ. Sci. 2019, 40, 2143-2151. [CrossRef]

3. Jiménez-Madrid, A.; Gogu, R.; Martinez-Navarrete, C.; Carrasco, F. Groundwater for human Consumptionin karst environment: Vulnerability, protection, and management. In The Handbook of Environmental Chemistry Book Series: Karst Water Environment, 1st ed.; Younos, T., Schreiber, M., Eds.; Springer International Publishing: Cham, Switzerland, 2018; Volume 68, pp. 46-61.

4. Ji, M.C.; Zhang, J.Q.; Peng, Y.; Ma, Q.Y. Research on the resistances of several kinds of hydrophyte to Lead in hydroponic condition. Biotechnol. Bull. 2017, 33, 120-125. [CrossRef]

5. Saxena, G.; Bharagava, R.N. Organic and inorganic pollutants in industrial wastes, their ecotoxicological effects, health hazards and bioremediation approaches. In Environmental Pollutants and Their Bioremediation Approaches, 1st ed.; Bharagava, R.N., Ed.; CRC Press: Boca Raton, FL, USA, 2017; pp. $23-56$. 
6. Zhang, H.X.; Huo, S.L.; Yeager, K.M.; Xi, B.D.; Zhang, J.T.; He, Z.S.; Ma, C.Z.; Wu, F.C. Accumulation of arsenic, mercury and heavy metals in lacustrine sediment in relation to eutrophication: Impacts of sources and climate change. Ecol. Indic. 2018, 93, 771-780. [CrossRef]

7. Yi, Z.J.; Yao, J.; Chen, H.L.; Wang, F.; Yuan, Z.M.; Liu, X. Uranium biosorption from aqueous solution onto Eichhornia crassipes. J. Environ. Radioact. 2016, 154, 43-51. [CrossRef] [PubMed]

8. Feng, W.; Xiao, K.; Zhou, W.B.; Zhu, D.W.; Zhou, Y.Y.; Yuan, Y.N.; Xiao, N.D.; Wan, A.Q.; Hua, Y.M.; Zhao, J.W. Analysis of utilization technologies for Eichhornia crassipes biomass harvested after restoration of wastewater. Bioresour. Technol. 2017, 223, 287-295. [CrossRef]

9. Mahamadi, C.; Nharingo, T. Utilization of water hyacinth weed (Eichhornia crassipes) for the removal of $\mathrm{Pb}(\mathrm{II}), \mathrm{Cd}(\mathrm{II})$ and $\mathrm{Zn}(\mathrm{II})$ from aquatic environments: And adsorption isotherm study. Environ. Technol. 2010, 31, 1221-1228. [CrossRef]

10. Suryandari, M.K.; Hariati, A.M.; Mahmudi, M. Removal of Lead from water by Eichhornia crassipes (Mart.) Solms. Imp. J. Interdiscip. Res. 2017, 3, 2387-2392.

11. Hirschi, K.D. The calcium conundrum: Both versatile nutrient and specific signal. Plant Physiol. 2004, 136, 2438-2442. [CrossRef]

12. Zaki, F.T.; Fathi, A.A. Impact of copper on some physiological aspects of Nostoc muscorum with special references to the detoxifying role of calcium. Acta Bot. Hung. 2004, 46, 423-433. [CrossRef]

13. Liu, L.L.; Feng, T.; Xiang, Y.C.; Xiao, L.; Yan, M.L. Effect of exogenous calcium on seedling growth and physiological characteristics of Brassica Juncea under cadmium stress. J. Agro Environ. Sci. 2009, 28, 978-983. [CrossRef]

14. Lu, L.L.; Tian, S.K.; Zhang, M.; Zhang, J.; Yang, X.E.; Jiang, H. The role of Ca pathway in Cd uptake and translocation by the hyperaccumulator Sedum alfredii. J. Hazard. Mater. 2010, 183, 22-28. [CrossRef]

15. Liao, X.X.; Chen, T.B.; Xiao, X.Y.; Huang, Z.C.; An, Z.Z.; Mo, L.Y.; Li, W.X.; Chen, H.; Zheng, Y.M. Spatial distributions of arsenic in contaminated paddy soils. Geogr. Res. 2003, 9, 635-643. [CrossRef]

16. Calile, N.; Swanwick, S.; Zhao, F.J.; McGrath, S.P. Arsenic hyperaccumulation by Pteris vittata from arsenic contaminated soils and the effect of liming and phosphate fertilisation. Environ. Pollut. 2004, 132, 113-120. [CrossRef] [PubMed]

17. Min, H.L.; Can, S.J.; Xu, Q.S.; Shi, G.X. Effects of exogenous calcium on resistance of Hydrilla verticillata (L.f.) Royle to cadmium stress. Acta Ecol. Sin. 2012, 32, 256-264. [CrossRef]

18. Heeraman, D.A.; Claassen, V.P.; Zasoski, R.J. Interaction of lime, organic matter and fertilizer on growth and uptake of arsenic and mercury by Zorro fescue (Vu lpia myuros L.). Plant Soil 2001, 234, 215-231. [CrossRef]

19. Zhang, L.K.; Qin, X.Q.; Huang, Q.B.; Liu, P.Y.; Shan, X.J. Aquatic plants bioremediation to groundwater contaminated by mines in karst areas. Carsologica Sin. 2017, 36, 743-750. [CrossRef]

20. Yin, X.Q.; Saha, U.; Ma, L. Effectiveness of best management practices in reducing Pb-bullet weathering in a shooting range in Florida. J. Hazard. Mater. 2010, 179, 895-900. [CrossRef]

21. Yang, S.F.; Zhao, M.J.; Li, J.S.; Feng, J.; Liu, Q. Removal of Zinc and Lead from blast furnace dust in a fluidized-bed roaster. J. Sustain. Metall. 2017, 3, 441-449. [CrossRef]

22. Xie, S.J. Study on the Enrichment Characteristics of Heavy Metals in Epipremnum aureum and Related Mechanisms; Ocean University of China: Qingdao, China, 2015.

23. Shi, H.P.; Wang, Y.L.; Eric, T.; LeeWah, C. Alleviated affect of exogenous $\mathrm{CaCl}_{2}$ on the growth, antioxidative enzyme activities and cadmium absorption efficiency of Wedelia trilobata hairy roots under cadmium stress. Chin. J. Biotechnol. 2012, 28, 747-762. [CrossRef]

24. Li, H.B.; Wei, H.B.; Hu, C.J.; Fu, L.Z.; Wu, X.Q.; Wu, Q.Q. Inhibitory effect of exogenous $\mathrm{Ca}^{2+}$ on accumulation of heavy metals in Lentinula edodes. For. Prod. Spec. China 2013, 127, 1-4. [CrossRef]

25. Farahat, E.; Linderholm, H.W. The effect of long-term wastewater irrigation on accumulation and transfer of heavy metals in Cupressus sempervirens leaves and adjacent soils. Sci. Total. Environ. 2015, 512, 1-7. [CrossRef]

26. Guan, B.T.H.; Mohamat-Yusuff, F.; Halimoon, N.; Yong, C.S.Y. Uptake of Mn and Cd by wild Water Spinach and their bioaccumulation and translocation factors. Environ. Asia. 2017, 10, 44-51. [CrossRef]

27. Sarital, S.; Rohit, S.; Shraddha, S. Comparative studies on accumulation of Cr from metal solution and tannery effluent under repeated metal exposure by aquatic plants: Its toxic effects. Environ. Monit. Assess. 2002, 80, 17-31. [CrossRef] 
28. Woldemichael, D.; Zewge, F.; Leta, S. Potential of water Hyacinth (Eichhornia Crassipes (Mart.) Solms) for the removal of chromium from trannery effluent in constructed pond system. Ethiop. J. Sci. 2011, 34, 49-62.

29. Han, L.H.; Zhang, Y.P.; Di, X.M.; Huang, A.L.; Liu, C. Anatomical characteristics and ecological adaptability of vegetative organs of three invasive plants. Jiangsu Agric. Sci. 2018, 46, 92-95. [CrossRef]

30. Rani, S.; Sumanjit, K.; Mahajan, R.K. Comparative study of surface modified carbonized Eichhornia crassipes for adsorption of dye safranin. Sep. Sci. Technol. 2015, 50, 2436-2447. [CrossRef]

31. Malar, S.; Vikram, S.S.; Favas, P.J.C.; Perumal, V. Lead heavy metal toxicity induced changes on growth and antioxidative enzymes level in water hyacinths [Eichhornia crassipes (Mart.)]. Bot Stud. 2014, 55, 54-65. [CrossRef]

32. Brunet, J.; Repellin, A.; Varrault, G.; Terrync, N.; Zuily-fodil, Y. Lead accumulation in the roots of grass pea (Lathyrus sativus L.): A novel plant for phytoremediation systems. CR Biol. 2008, 331, 859-864. [CrossRef]

33. Yang, Y.J.; Wang, B.; Guo, X.J.; Zou, C.W.; Tan, X.D. Investigating adsorption performance of heavy metals onto humic acid from sludge using Fourier-transform infrared combined with two-dimensional correlation spectroscopy. Environ. Sci. Pollut. Res. 2019, 26, 9842-9850. [CrossRef]

34. Guo, X.J.; Li, C.W.; Zhu, Q.L.; Huang, T.; Cai, Y.; Li, N.X.; Liu, J.Y.; Tan, X.D. Characterization of dissolved organic matter from biogas residue composting using spectroscopic techniques. Waste Manag. 2018, 78, 301-308. [CrossRef]

35. Li, Q.; Chen, B.; Lin, P.; Zhou, J.L.; Zhan, J.H.; Shen, Q.Y.; Pan, X.J. Adsorption of heavy metal from aqueous solution by dehydrated root powder of Long-root Eichhornia crassipes. Int. J. Phytorem. 2014, 18, 103-109. [CrossRef] [PubMed]

36. Li, Q. Research on Removal Mechanisms of Four Kinds of Heavy Metals in Water by Long-Root Eichhornia crassipes and Its Recycling; Kunming University Science and Technology: Kunming, China, 2015.

37. Han, R.P.; Li, J.J.; Yang, G.Y.; Bao, G.L. Comparison of infrared spectroscopy between native and binding metals' phytoplankton. Spectrosc. Spectr. Anal. 2000, 20, 489-491. [CrossRef]

38. Wang, H.X. Ecology of Pollution; Higher Education Press: Beijing, China; Springer Press: Berlin, Germany, 2000.

39. Cai, C.X.; Wang, H.M.; Zhang, C.M. Studies on beneficiation mechanism and speed rate of removal of five heavy metalic ions by Water Gourd. J. Youjiang Teach. Coll. Natl. Guangxi 2002, 15, 48-51. [CrossRef]

40. Xia, W. Preparation of Biochar and Adsorption of Heavy Metals in Soil; Nanjing Normal University: Nanjing, China, 2016.

41. Jang, H. Environmental Hydrochemistry; Chemistry Industry Press: Beijing, China, 2013. 